\section{Occurrence of Chthamalus stellatus (Poli) in Fair Isle and Shetland}

The Mediterranean/Atlantic littoral barnacle, Chthamalus stellatus (Poli), is at the northern limit of its range in Britain, and is confined to the southwest, west and north coasts. In the English Channel it is not recorded east of Swanage ${ }^{1,2}$ and Flamanville ; but there are a few old records for two places far beyond these limits-at and near Heligoland (recorded several times during the nineteenth century ${ }^{3}$, but stated to be absent by more recent authors), and in the harbour at Anholt in the Kattegat (present March 1913, but absent in $\left.1934^{4}\right)$. The most northerly records to date are those for north-east Scotland ${ }^{1}$ (confirmed during 1951 by Dr. J. R. Lewis and me), where the species is finally represented only by sparsely scattered, but well-developed, individuals ; Stephensen's record for "Norway, S. of Lofoten"s would appear to be in error.

It is therefore of interest to record the presence of $C$. stellatus on the mainland of Shetland, as well as on Fair Isle, during June 1952; in all cases Chthamalus occurred above a belt of Balanus balanoides :

1. Shetland (June 24): Chthamalus scarce on the only exposed coast examined, in the south-west of the mainland (in Muckle Sound, just north of Spiggie Voe; position $59^{\circ} 56^{\prime} 46^{\prime \prime}$ N., $1^{\circ} 20^{\prime} 32^{\prime \prime}$ W.). Eleven of the larger barnacles were collected, and measured as follows: mean rostro-carinal length $7 \cdot 6 \mathrm{~mm}$. (range $4 \cdot 8-10 \cdot 0 \mathrm{~mm}$.); mean breadth $6 \cdot 7 \mathrm{~mm}$. $(4 \cdot 5-9 \cdot 5 \mathrm{~mm}$.). Only three of these specimens were growing sufficiently close together to have been capable of cross-fertilization, and only these contained early-stage embryos.

2. Fair Isle : a number of coasts were examined, but Chthamalus was found only at the following two exposed places : (i) east coast (June 25)—scarce, at tip of headland (Landberg) on east flank of Mavers Geo $\left(59^{\circ} 32^{\prime} 7 \cdot 6^{\prime \prime}\right.$ N., $1^{\circ} 36^{\prime} 22 \cdot 5^{\prime \prime}$ W.). (ii) South-west coast (June 30)-frequent, on very exposed reefs south-west of South Lighthouse $\left(59^{\circ} 30^{\prime} 50 \cdot 7^{\prime \prime} \mathrm{N}\right.$., $1^{\circ} 39^{\prime} 7 \cdot 4^{\prime \prime}$ W.) ; twenty-six of the larger barnacles were collected, and nineteen undamaged specimens measured, as follows : mean length $9.0 \mathrm{~mm}$. (range $6 \cdot 1-11 \cdot 2 \mathrm{~mm}$.), mean breadth $8 \cdot 9 \mathrm{~mm}$. $(6 \cdot 0-12 \cdot 2 \mathrm{~mm}$.). Sixteen of the twenty-six barnacles contained developing embryos; the least developed were at a very early stage, but the most advanced were quite mature, measured $0.23 \times 0.13 \mathrm{~mm}$. (size of egg-case ; mean of twenty-five from largest barnacle), with some ready to release nauplii.

The sizes of $C$. stellatus at these new northern limits of its range are comparable with the mean and maximum sizes attained in the Firth of Clyde (personal observations), the Isle of $\operatorname{Man}^{6}$, and Lancashire ${ }^{2}$, and with the largest mean sizes recorded near Plymouth $(6.0 \mathrm{~mm}$. mean diameter at an estimated age of four years $)^{1}$ and near St. Malo $(6 \cdot 3 \mathrm{~mm}$. after three years growth in an exposed situation) ${ }^{7}$. The sizes of the largest barnacles suggest at least three or four years growth. Thus growth is not inhibited and there was no evidence of abnormal mortality or sterility of either young or old barnacles, such as might be expected if, as has been suggested by several authors, low winter temperatures were critical for survival of the species at the northern limits of its range.

These observations lend support rather to the view that the present over-all limits of distribution of
C. stellatus on British coasts are probably determined by factors affecting survival of the planktonic larval stages rather than of the hardy adult bornacles. In this respect it is of interest that at least some larvæ in Shetland waters must have survived lower summer surface seawater temperatures (maximum in August $11^{\circ}-13^{\circ}$ C.) than are normally found anywhere else around the British Isles or throughout the North Sea 8,8 . Further, seawater temperatures off southwest England are normally higher from June to November than the Shetland August maximum, suggesting that both the reported failure of the early and late broods in the south-west ${ }^{2}$, and the absence of $C$. stellatus east of Swanage, are due to environmental factors that are unfavourable for survival of larvæ in some respect other than a direct temperature effect. These unknown limiting factors could be a shortage or absence of suitable planktonic food organisms at the appropriate time of year, and/or a generally unfavourable chemical environment (cf. the observations of Wilson 10 on the poor survival of larva of certain other marine invertebrates in Channel water as compared with Atlantic water).

Marine Station,

H. T. POWELL Millport,

Isle of Cumbrae. Dec. 16.

${ }^{1}$ Moore, H. B., and Kitching, J. A., J. Mar. Biol. Assoc. U.K., 23. 521 (1939).

${ }^{2}$ Crisp, D. J., Nature, 166, 311 (1950).

${ }^{3}$ Weltner, W., Wiss. Meeresuntersuch., N.F., 2, 437 (1897).

4 Poulsen, E. M., Vidensk. Medd. Dansk. Naturh. Foren. Kbh., 99. 5 (1936).

${ }^{5}$ Stephensen, K., Zool. Faeroes, 2, Pt. 27 (1929).

- Southward, A. J., Nature, 165, 408 (1950).

'Hatton, H., Ann. Inst. Océanogr. Monaco, N.S., 17, 241 (1938).

8 Deutschen Seewarte Hamburg, "Atias für Temperatur, Salzegehalt und Dichte der Nordsee und Ostsee" (1927). - Cons. Internat. Explor. Mer, monthly charts of surface water
temperature, etc., June 1950 to June 1953 .

${ }_{10}$ Wilson, D. P., J. Mar. Biol. Assoc. U.K., 30, 1 (1951).

\section{Ants Myrmica rubra L. and $M$. scabrinodis Nylander as Intermediate Hosts of a Cestode}

DURING recent ecological investigations of the ant fauns of heather moor in the west of Scotland, two of the commonest species in this region, Myrmica rubra L.' and $M$. scabrinodis Nylander, have been found to be acting as the intermediate hosts of a cestode. The cysticercoids lie freely in the body cavity and are extruded as soon as the cuticle is ruptured. They are ellipsoidal in shape (Fig. 1), measuring $530-700 \mu$ by $340-400 \mu$, are very active and contain numerous calcareous granules. No suggestion of a cercomere has yet been seen. The larval scolex is often extruded very soon after the cysticercoid is removed from the ant and placed in saline. In most cases the scolex breaks away from the cyst, the rupture occurring at the base of the larval neck, and thereafter it progresses by movements of the suckers.

The dimensions of the scolex vary with the state of contraction; but in its relaxed condition it is approximately $300 \mu$ long by $180 \mu$ in diameter. The rostellar ring is $50-60 \mu$ in diameter and consists 